\title{
Best parameters for sexual dimorphism in the facial thickness tissue with ultrasonic assessment
}

\author{
Iván Claudio Suazo Galdames', Guillermo Enrique Salgado Alarcón², \\ Daniela Alejandra Zavando Matamala ${ }^{3}$
}

Galdames ICS, Alarcón GES, Matamala DAZ. Best parameters for sexual dimorphism in the facial thickness tissue with ultrasonic assessment. Saúde, Ética \& Justiça. 2008;13(2):60-4

Aвstract: Knowledge of facial tissue thickness is crucial to facial reconstruction procedures in forensic sculpture. The literature still brings some controversy on the validity of data obtained for different population groups. The purpose of this study was to investigate sexual dimorphism in the thickness of the facial tissues. The study sample consisted of 43 volunteers, between 24 and 48 years of age, and of normal body mass. Ultrasound measurements of facial tissue thickness were obtained at 14 median and paramedian landmarks. A T test was used to compare measurements from males and females, with a significance level of at least 0.05 . Discriminant function analysis was used to determine the points that showed most distinction between the sexes. Measurements at paramedian landmarks were greater in males, while those at median landmarks were greater in female subjects, except for Down's A and B points. We conclude that sexual dimorphism in facial thickness justifies the pre-assignment of sex in reconstruction procedures in forensic sculpture

KEYwORDs: Tissue thickness. Sex characteristics. Forensic anthropology. Face/ultrasonography. Imaging processong, computer assisted/legislation \& jurisprudence.

INTRODUCTION

$\mathrm{K}$ nowledge of facial tissue thickness is necessary to carry out facial reconstruction using the anatomical landmarks of the skull1-4.

The reconstruction process is based on the fact that the facial soft tissue develops with the skull according to embryonic and evolutionary parameters.
Wilkinson et al. ${ }^{5}$ pointed out that the cranial bony tissue is the matrix for the development of the head and serves as a base for the soft tissues. Smith and Buschang ${ }^{6}$ have also observed this relationship between bony and soft tissues, concluding that facial pattern depends on the proportions of the bony tissue. These relationships are important for aesthetic prediction in orthodontic treatment. For

\footnotetext{
DDS, MSc, Professor \& Head, Department of Normal Anatomy, Universidad de Talca, Chile. Associated Professor in Anatomy. Associated in Science in Anthropology.

2 DDS, MSc student Universidad de la Frontera, Temuco, Chile.

3 DDS, MSc student Universidade Federal de São Paulo - Escola Paulista de Medicina

Endereço PaRA correspondênCIA: Prof. Dr. Iván Suazo Galdames, DDS. MSc. Professor \& Head, Department of Normal Anatomy, Universidad de Talca, Chile. Lircay street s/n office Nº104. E-mail: isuazo@ utalca.cl
} 
Hoffelder et al. ${ }^{7}$ there are multiple points on the facial soft tissue that express sexual dimorphism in individuals over 16 years of age.

Relationships between the facial soft tissues and skull have been analyzed by different authors ${ }^{3,4,8}$, in attempts to improve the result of facial reconstruction for forensic purposes.

For Domaracki and Stephan ${ }^{9}$, assignment of ethnic affiliation, sex and age are prerequisite steps to facial reconstruction, since facial tissue thicknesses vary accordingly.

Several methods have been used to assess facial soft tissue thickness. Stephan and Henneberg ${ }^{10}$ analyzed the needle puncture method in cadavers. They carried out facial reconstructions using published data and obtained low recognition levels, concluding that measurement with needles was not very reliable. Suazo et al. ${ }^{11}$ compared tissue thickness measurements with needles in fresh and embalmed cadavers, concluding that facial tissue thickness was significantly greater in cadavers that had been previously fixed at at least 11 of the 20 points analyzed. They concluded that conservation methods should be taken into consideration in order to carry out reliable comparisons between methods or to apply thickness tissue tables in practice.

The main confounding factor in determining tissue thickness in cadavers is the physical phenomenon of soft tissue dehydration ${ }^{12,13}$.

Greater reliability has been reported by De Greef and Willems ${ }^{14}$ with roegentographic applications in teleradiography and tomography, but with the disadvantages of patient irradiation and higher costs ${ }^{15}$.

El-Mellawi and Soliman ${ }^{16}$ reported that facial tissue thickness underlies sexual dimorphism in adults, being greater in females than in the males, especially at the regions of the cheek, lip, chin and jaw ${ }^{17}$; similar results were reported by Suazo et al. ${ }^{13}$, who have found wider soft tissues at paramedian landmarks in females, and at median landmarks in males, in a study of Spanish cadavers.

Several authors have reported different results regarding soft tissue thickness in different ethnic groups $^{18-20}$. Satravaha ${ }^{21}$ demonstrated that tissue depth measurements were valid within the ethnic group in which the study was carried out.

In the Chilean population studies are scarce. With this issue in mind, Suazo et al. ${ }^{22}$ evaluated facial tissue thickness differences in relation to sex and age in a sample of adult Chileans.
The aim of this study is to verify parameters of facial tissue thickness obtained from different anatomical landmarks on the skull using an ultrasonic assessment.

\section{SubJeCtS AND METHOdS}

The sample comprised of 43 Chilean adults, 22 females and 21 males, of between 24 and 48 years of age (Mean 38.72 years, SD 8.02), with a normal weight-size ratio (Body Mass index: mean 21,48, SD $2,96)$. In order to participate in the study, volunteers signed an informed consent agreement and the study was approved by the local ethics committee.

Exclusion criteria were: presence of facial deformities or scars, and patients who had undergone procedures of facial plastic or orthognathic surgery.

In the selected sample, the following points were identified:

Median Points: Supraglabella, Glabella, Nasion, A of Downs, B of Downs, Pogonion, Gnathion.

Left paramedian points: Superciliare, Supraorbital, Exocanthion, Infraorbiatal, Zygion, Mental foramen, Gonion.

A General Electric $₫$ Voulson 730 Ultrasound system was used with a transducer of $50 \mathrm{~mm}$ and standard conductor gel. Tissue thickness values were measured in millimeters from the external surface of the skin to the bony plane in a perpendicular line.

The sample was measured by a single specialist. The intraobserver error was estimated by means of the double measurement method, and the variation ranged from 0.1 to $0.8 \mathrm{~mm}$.

The software SPSS 15.0 was used to perform a descriptive statistical analysis using a $T$ test with a significance level of $p<0.05$. For the purpose of evaluating the possibility of sex assessment using tissue depths, an analysis using Fischer's linear discriminant function was carried out at the same significance level.

\section{REsULts}

The highest tissue depth values were obtained at the gonion, located on the mandible (mean $=16.32 \mathrm{~mm}$, $S D=1.53$ and mean=13.10, SD=1.74 for males and females, respectively) and at the mental forament (mean=11.881, SD=1.04 and mean $=11.364, \mathrm{SD}=0.4$, for males and females, respectively). 
In males, lower values were obtained at the superciliare (mean $=4.948, \mathrm{SD}=0.32$ ) and glabella (mean $=4.990, \mathrm{SD}=0.374)$, and in females, at the supraglabella (mean $=4.882, \mathrm{SD}=0.529$ ).

Five of the 14 analyzed depths presented higher mean values for males at the following landmarks: A of Downs, $B$ of Downs, infraorbital and gonion ( $p$ $<0.01)$, and mental foramen $(p<0.05)$. Facial tissue thickness values measured at the supraglabella, supraorbital and exocanthion landmarks seemed to be greater in males. The difference was not statistically significant, however. In females, facial thickness values were higher at the glabella and superciliare $(p<0.005)$, and the zigion $(p<0.05)$. Higher values were also obtained at the nasion, pogonion and gnathion, without statistical significance, however.

Table 1 shows the descriptive statistical analysis and the significance of the differences of the thickness tissue measured in the 14 points of the face are shown.

After applying discriminant function analysis we observed that the best points for the sex discrimination are: the supraglabella, nasion, A of Downs, exocanthion $y$ and the zigion, where linear combinations archieve 100 percent accuracy (Table 2 ).

Table 1 - Descripive statistical of the facial thickness tissue in 14 face landmarks in 43 adults chilean

\begin{tabular}{|c|c|c|c|c|c|c|}
\hline Landmark & Sex & $\mathbf{N}$ & Mean & SD & TE & $P$ value \\
\hline Supraglabella & $\begin{array}{l}\text { Female } \\
\text { Male }\end{array}$ & $\begin{array}{l}22 \\
21\end{array}$ & $\begin{array}{l}4.882 \\
5.038 \\
\end{array}$ & $\begin{array}{l}.5297 \\
.3369 \\
\end{array}$ & $\begin{array}{l}.1129 \\
.0735 \\
\end{array}$ & .258 \\
\hline glabella & $\begin{array}{l}\text { Female } \\
\text { Male }\end{array}$ & $\begin{array}{l}22 \\
21\end{array}$ & $\begin{array}{l}5.332 \\
4.990 \\
\end{array}$ & $\begin{array}{l}.5601 \\
.3740 \\
\end{array}$ & $\begin{array}{l}.1194 \\
.0816 \\
\end{array}$ & $.024^{*}$ \\
\hline nasion & $\begin{array}{l}\text { Female } \\
\text { Male }\end{array}$ & $\begin{array}{l}22 \\
21 \\
\end{array}$ & $\begin{array}{l}5.445 \\
5.257 \\
\end{array}$ & $\begin{array}{l}.3405 \\
.5861 \\
\end{array}$ & $\begin{array}{l}.0726 \\
.1279 \\
\end{array}$ & .202 \\
\hline A of downs & $\begin{array}{l}\text { Female } \\
\text { Male }\end{array}$ & $\begin{array}{l}22 \\
21 \\
\end{array}$ & $\begin{array}{c}9.514 \\
10.600 \\
\end{array}$ & $\begin{array}{l}.8079 \\
.6473 \\
\end{array}$ & $\begin{array}{l}.1722 \\
.1413 \\
\end{array}$ & $.000^{\star *}$ \\
\hline B of Downs & $\begin{array}{l}\text { Female } \\
\text { Male }\end{array}$ & $\begin{array}{l}22 \\
21\end{array}$ & $\begin{array}{c}9.055 \\
10.448\end{array}$ & $\begin{array}{l}.5779 \\
.9119\end{array}$ & $\begin{array}{l}.1232 \\
.1990\end{array}$ & $.000^{\star *}$ \\
\hline pogonion & $\begin{array}{l}\text { Female } \\
\text { Male }\end{array}$ & $\begin{array}{l}22 \\
21\end{array}$ & $\begin{array}{l}9.668 \\
9.590 \\
\end{array}$ & $\begin{array}{l}.6542 \\
.7063 \\
\end{array}$ & $\begin{array}{l}.1395 \\
.1541 \\
\end{array}$ & .710 \\
\hline gnathion & $\begin{array}{l}\text { Female } \\
\text { Male }\end{array}$ & $\begin{array}{l}22 \\
21\end{array}$ & $\begin{array}{l}7.314 \\
6.843\end{array}$ & $\begin{array}{c}1.5385 \\
.8164\end{array}$ & $\begin{array}{l}.3280 \\
.1782\end{array}$ & .220 \\
\hline Superciliare & $\begin{array}{l}\text { Female } \\
\text { Male }\end{array}$ & $\begin{array}{l}22 \\
21\end{array}$ & $\begin{array}{l}5.982 \\
4.948 \\
\end{array}$ & $\begin{array}{c}1.7350 \\
.3250 \\
\end{array}$ & $\begin{array}{l}.3699 \\
.0709 \\
\end{array}$ & $.010^{\star}$ \\
\hline Supraorbital & $\begin{array}{l}\text { Female } \\
\text { Male }\end{array}$ & $\begin{array}{l}22 \\
21 \\
\end{array}$ & $\begin{array}{l}5.736 \\
5.895 \\
\end{array}$ & $\begin{array}{l}.4583 \\
.3122 \\
\end{array}$ & $\begin{array}{l}.0977 \\
.0681 \\
\end{array}$ & .193 \\
\hline Exocanthion & $\begin{array}{l}\text { Female } \\
\text { Male }\end{array}$ & $\begin{array}{l}22 \\
21 \\
\end{array}$ & $\begin{array}{l}5.118 \\
5.233 \\
\end{array}$ & $\begin{array}{l}.5465 \\
.8708 \\
\end{array}$ & $\begin{array}{l}.1165 \\
.1900 \\
\end{array}$ & .605 \\
\hline Infraorbiatal & $\begin{array}{l}\text { Female } \\
\text { Male }\end{array}$ & $\begin{array}{l}22 \\
21 \\
\end{array}$ & $\begin{array}{l}6.032 \\
6.943 \\
\end{array}$ & $\begin{array}{c}1.0807 \\
.3842 \\
\end{array}$ & $\begin{array}{l}.2304 \\
.0838 \\
\end{array}$ & $.001^{\star *}$ \\
\hline Zygion & $\begin{array}{l}\text { Female } \\
\text { Male }\end{array}$ & $\begin{array}{l}22 \\
21 \\
\end{array}$ & $\begin{array}{c}10.264 \\
7.705 \\
\end{array}$ & $\begin{array}{l}.5278 \\
.9952 \\
\end{array}$ & $\begin{array}{l}.1125 \\
.2172 \\
\end{array}$ & .000 \\
\hline Mental foramen & $\begin{array}{l}\text { Female } \\
\text { Male }\end{array}$ & $\begin{array}{l}22 \\
21 \\
\end{array}$ & $\begin{array}{l}11.364 \\
11.881\end{array}$ & $\begin{array}{c}.4054 \\
1.0419\end{array}$ & $\begin{array}{l}.0864 \\
.2274\end{array}$ & $.036^{\star}$ \\
\hline Gonion & $\begin{array}{l}\text { Female } \\
\text { Male }\end{array}$ & $\begin{array}{l}22 \\
21\end{array}$ & $\begin{array}{l}13.100 \\
16.362\end{array}$ & $\begin{array}{l}1.7422 \\
1.5361\end{array}$ & $\begin{array}{l}.3714 \\
.3352\end{array}$ & $.000^{* *}$ \\
\hline
\end{tabular}

* Statistical significance $p<0.05$

** Statistical significance $p<0.01$ 
Table 2. Discriminated function coefficients and accuracy of sex determination from thickness tissue

\begin{tabular}{l|cc}
\hline Landmark & Female & Male \\
\hline Supraglabella & -25.930 & -8.740 \\
Nasion & 43.213 & 35.170 \\
A of Downs & 9.020 & 16.632 \\
Exocanthion & 3.640 & -7.850 \\
Zygion & 36.026 & 21.617 \\
(Constant) & -292.164 & -222.014 \\
& & \\
\hline Percent accuracy & $100 \%$ & $100 \%$ \\
\multicolumn{1}{c}{$\mathrm{N}$} & $22 / 22$ & $21 / 21$ \\
\hline
\end{tabular}

\section{Discussion}

This study has established facial tissue thickness parameters at median and paramedian landmark points through ultrasonic assessment, in relation to sexual dimorphism in a group of Chilean adults. Results showed that only some parameters could be successfully applied for sex estimation, which supports the remarks of Stephan et al. ${ }^{23}$ concerning the relevance of sex determination from the skeleton as a prerequisite to facial reconstruction.

In this sample, females presented greater tissue thickness at the median points, except for those related with the alveolar process. Consequently, male subjects presented greater tissue thickness at the paramedian points, especially in the mandibular region. These results are in partial agreement with those reported by El-Mellawi and Soliman ${ }^{16}$ who described greater tissue thickness in females at some median and paramedian points. On the other hand these results differ with those found by Suazo et al. ${ }^{13}$ in a study carried out using the needle puncture technique in cadavers.

The high percentage of subjects correctly classified using the discriminant analysis confirms the presence of sexual dimorphism in facial tissue thickness in the sample analyzed. Samples with a wider dispersion in age would probably present more discrete differences.

Knowledge of the normal ranges of facial tissue thicknesses in normal subjects is important to increased accuracy in facial reconstructions and the data obtained in this study contributes in the context of reconstructions in the Chilean population.

Galdames ICS, Alarcón GES, Matamala DAZ. Best parameters for sexual dimorphism in the facial thickness tissue with ultrasonic assessment. Saúde, Ética \& Justiça. 2008;13(2):60-4

REsumo: O conhecimento das espessuras tissulares faciais é necessário para a reconstrução por escultura forense, no entanto discute-se a respeito da validade dos dados obtidos a partir de outros grupos populacionais. O propósito deste estudo foi analizar a presença de dimorfismo sexual nas espessuras tissulares. Participaram neste estudo 43 pacientes voluntários, com idades entre 24 e 48 anos, e índice de massa corporal normal. Utilizando-se um ultra-som, foram medidas as espessuras tissulares em 14 pontos medianos e paramedianos do rosto e a "relevância" das diferenças por sexo foram determinados mediante "teste T", com $p<0.01$ e $p<0.05$. Mediante análises da função "discriminante" foram determinados aqueles pontos que melhor permitem a classificação em homens e mulheres. Os homens apresentaram valores maiores nos pontos paramedianos da região mandibular enquanto, nas mulheres, estes foram maiores nos pontos medianos com exceção dos pontos A e B de Down. A presença de dimorfismo sexual nas espessuras tissulares faciais justifica a determinação do sexo como passo prévio aos procedimentos de reconstrução por escultura forense.

Descritores: Espessura tissular. Reconstrução facial. Antropologia forense. Face/ultra-sonografia. Caracteres sexuais. Processamento de imagem assistida por computador/legislação \& jurisprudência.

Artigo recebido em 08/10/2008. Aprovado em 12/09/2008.

\section{References}

1. Wilkinson CM. In vivo facial tissue depth measurements for white British children. J Forensic Sci. 2002;47:459-65.

2. Kustar A. The facial restoration of Antal Simon, a Hungarian priest-teacher of the 19th c. Homo. 2004:55:77-90.
3. Claes P, Vandermeulen D, De Greef S, Willems $G$, Suetens P. Craniofacial reconstruction using a combined statistical model of face shape and soft tissue depths: methodology and validation. Forensic Sci Int. 2006;159(Suppl 1):S147-58.

4. Utsuno $\mathrm{H}$, Kageyama $\mathrm{T}$, Deguchi $\mathrm{T}$, et al. Facial soft 
tissue thickness in skeletal type I Japanese children. Forensic Sci Int. 2007;172:137-43.

5. Wilkinson CM, Motwani M, Chiang E. The relationship between the soft tissues and the skeletal detail of the mouth. J Forensic Sci. 2003;48:728-32.

6. Smith SL, Buschang PH. Midsagittal facial tissue thicknesses of children and adolescents from the Montreal growth study. J Forensic Sci. 2001;46:1294302.

7. Hoffelder LB, de Lima EM, Martinelli FL, Bolognese AM. Soft-tissue changes during facial growth in skeletal class II individuals. Am J Orthod Dentofacial Orthop. 2007;131:490-5.

8. Bergman RT. Cephalometric soft tissue facial analysis. Am J Orthod Dentofacial Orthop. 1999;116:373-89.

9. Domaracki M, Stephan CN. Facial soft tissue thicknesses in Australian adult cadavers. J Forensic Sci. 2006;51:5-10.

10. Stephan CN, Henneberg M. Building faces from dry skulls: are they recognized above chance rates? J Forensic Sci. 2001;46:432-40.

11. Suazo GIC, Cantín LM, Zavando MDA, Perez RFJ, Torres MSR. Comparisions in soft-tissue thicknes on the human face in fresh and embalmed corpses using needle puncture method. Int J Morphol. 2008;26:1659.

12. De Greef $\mathrm{S}$, Claes $\mathrm{P}$, Vandermeulen $\mathrm{D}$, Mollemans $\mathrm{W}$, Suetens P, Willems G. Large-scale in-vivo Caucasian facial soft tissue thickness database for craniofacial reconstruction. Forensic Sci Int. 2006;159(Suppl 1):126-46.

13. Suazo GIC, Perez RFJ, Torres MSR. Grosores Tisulares faciales en cadáveres de españoles y su aplicación en la identificación médicolegal. Int $\mathrm{J}$
Morphol. 2007;25:109-16.

14. De Greef S, Willems G. Three-dimensional craniofacial reconstruction in forensic identification: latest progress and new tendencies in the 21st century. $J$ Forensic Sci. 2005;50:12-7.

15. Utsuno H, Kageyama T, Deguchi T, Yoshino M, Miyazawa $\mathrm{H}$, Inoue $\mathrm{K}$. Facial soft tissue thickness in Japanese female children. Forensic Sci Int. 2005;152:101-7.

16. El-Mehallawi IH, Soliman EM. Ultrasonic assessment of facial soft tissue thicknesses in adult Egyptians. Forensic Sci Int. 2001;117:99-107.

17. Lee SH. Patterns of size sexual dimorphism in Australopithecus afarensis: another look. Homo. 2005;56:219-32.

18. Aulsebrook WA, Becker PJ, Iscan MY. Facial softtissue thicknesses in the adult male Zulu. Forensic Sci Int. 1996;79:83-102.

19. Rhine JS, Campbell HR. Thickness of facial tissues in American blacks. J Forensic Sci. 1980;25:847-58.

20. Phillips VM, Smuts NA. Facial reconstruction: utilization of computerized tomography to measure facial tissue thickness in a mixed racial population. Forensic Sci Int. 1996;83:51-9.

21. Satravaha S, Schlegel KD. The significance of the integumentary profile. Am J Orthod Dentofacial Orthop.1987;92:422-6.

22. Suazo GIC, Salgado AGE, Cantin LMG. Evaluación ultrasonográfica del tejido blando facial en adultos chilenos. Int J Morphol. 2007;25:643-8.

23. Stephan CN, Norris RM, Henneberg M. Does sexual dimorphism in facial soft tissue depths justify sex distinction in craniofacial identification? J Forensic Sci. 2005;50:513-8. 